Sexing the Colorlines: Black Sexualities, Popular Culture, and Cultural Production

\title{
"Here's a Chance to Dance our Way Out of our Constrictions": P-Funk's Black Masculinity and the Performance of Imaginative Freedom
}

\section{Francesca T. Royster}

Department of English, DePaul University, Chicago, IL USA

Poroi, 7, 2 (J une 2011)

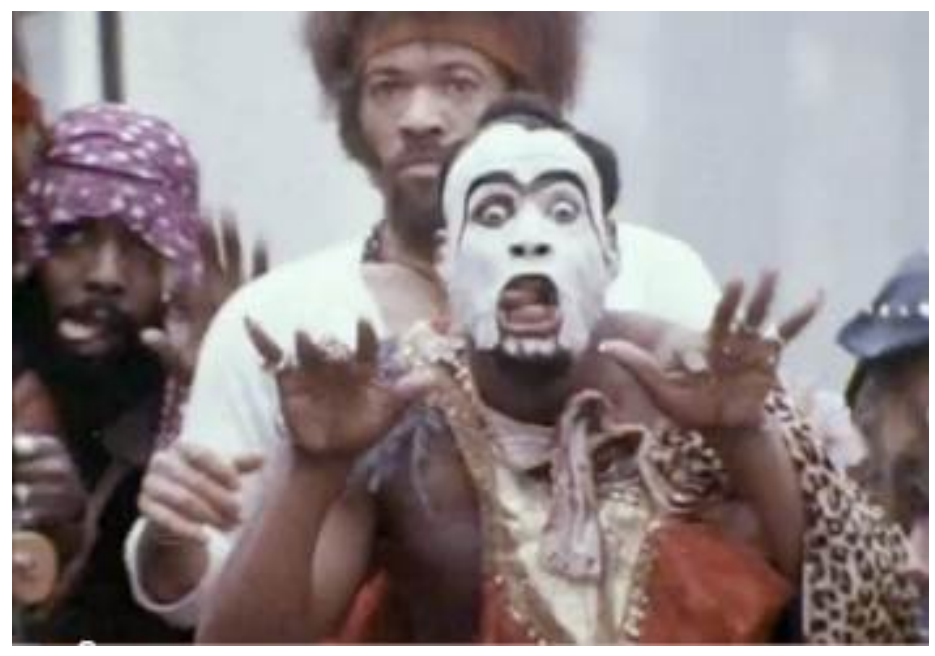

Funkadelic, "Cosmic Slop" (Film: Dir. Armen Bolodian, Westbound Records, 1973, as found on YouTube)

The men, funky in their sartorial groovyness, arms raised like birds, run from a city park tunnel, this everyday space of darkness and transition. The underpass is true in its particularity: it is somewhere in Central Park, a space to write graffiti, make love, share an illicit smoke. The urban park underpass, a dark pause in the middle of the green, the city turning in on itself, ripe with damp earth smells 
that seep into the concrete, along with the piss and smoke. It is the space where the wildlife of the park (animal, vegetable, and mineral) takes refuge. There are castaways and survivors--broken glass and pigeons. The men fly from this space, and they come running toward us, like children playing airplane, like Busby Berkeley dancers on 'shrooms, like serious visionaries, transformed in ceremony, this unclaimed black and brown and white tribe.

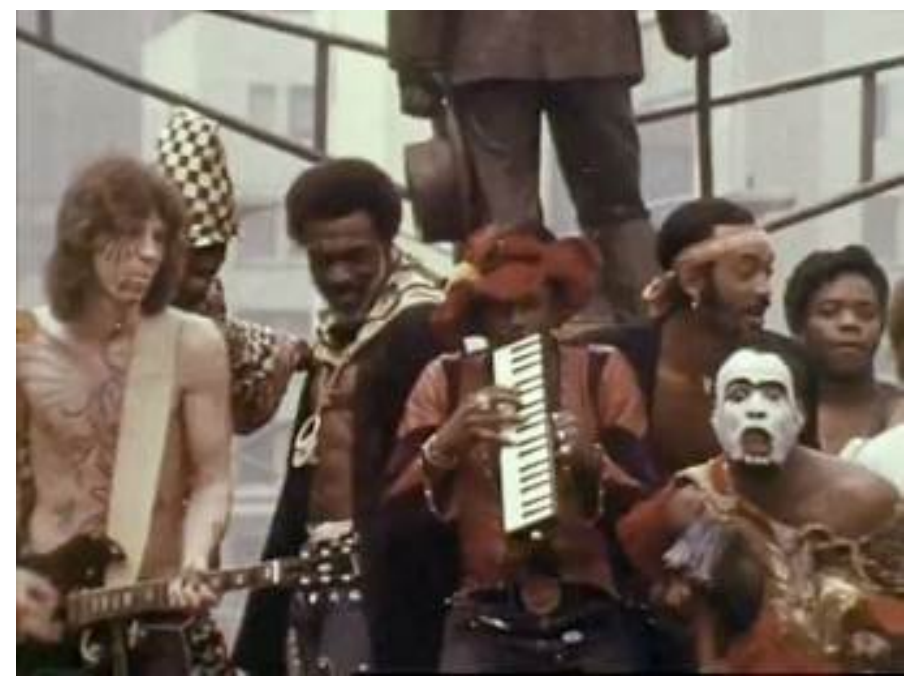

Released by the squeal of guitar, they take over the park and the streets beyond. The city, for once disinterested in them, becomes their playground. They congregate in front of a fountain, climb over park benches and into the streets like a wave; they are still steady in tight leathers and platform boots. Rhythm guitar driving them ever outward, they create a Soul Train line in the middle of Times Square. They move like birds do, in parabolas, looping, then circling away. They dance in mirror to each other, shoulders, hips and long thighs in call and response. Sometimes the men turn their backs to the camera, disoriented, lost in their own experience of beat; they close their eyes to follow internal geographies. They turn, stoop and crouch toward the camera, as if engaged in capoeira with it, as if ready to pounce. The camera matches them, meets them, and slows down their groove into tasty syrup. They do slow splits and they are superhuman in their flexibility. Their movements are loose and tight; they feel the flow and the force of drums on the back of their neck. There is laughter. The beat stays right on The One. ${ }^{1}$ Their

\footnotetext{
1 “The One,” coined by James Brown, is one of THE central musical aspects of funk: the use of the downbeat at
} 
faces squish up in the nastiness and in the stank of it. The men heat the air of the city, defy gravity, and take flight.

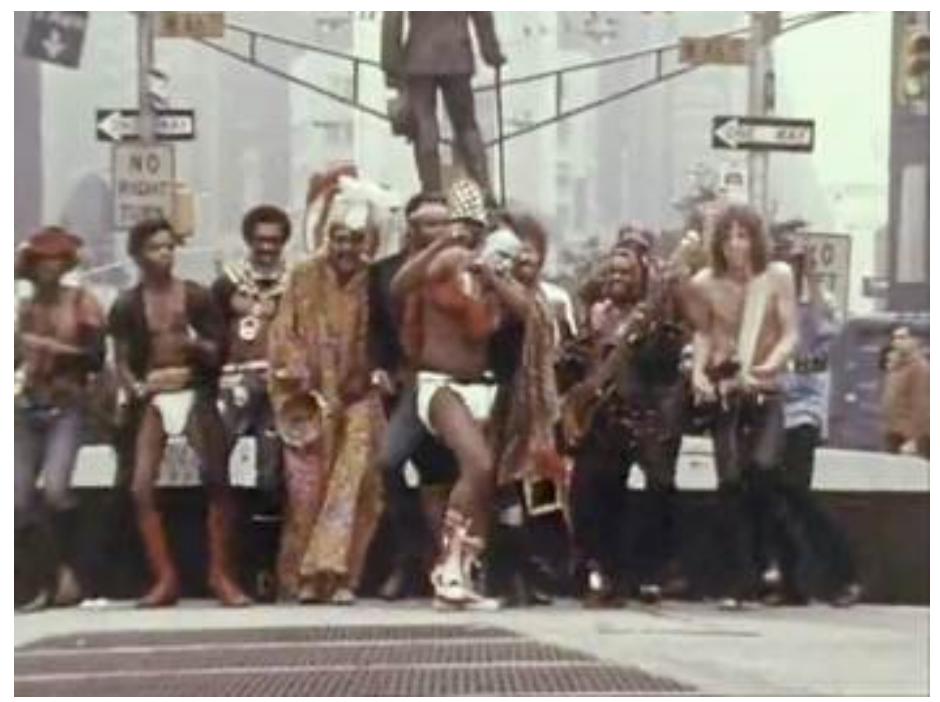

In this film made to accompany "Cosmic Slop," produced before the age of music videos in 1973 by Westbound Records, we see the vision and ethos of Parliament Funkadelic's lead and cofounder, George Clinton, in action: playful sexuality expressed by a tight beat and theatrical, body-conscious style; eccentric, exploratory individuality, as well as the power of the collective; a grounding in the everyday grittiness of black street culture, combined with the quest for imaginative freedom. Together with his ever expanding band, which over time included such luminaries as guitarist Eddie Hazel, bassist Bootsy Collins, lead singer Gary Shider, keyboardist and arranger Bernie Worrell, and cameo appearances by Sly Stone, Clinton changed the face and the feel of funk music, making it visionary, dangerous, hallucinatory, hilarious and very hot.

Once more, they are beautiful, these men, in wild and defiant Afros, shirtless, unmasked and masked. They are a parade of tricksters, all moving with the anti-discipline of funk: a wolf meets a griot, and King Tut meets a spaceman.

the beginning of every bar. But as Arthur Kempton points out in his study, Boogaloo: the Quintessence of American Popular Music, its meaning acquired wider symbolic meaning over time: “By the late 1970's, 'on the one' was a descriptor as well-applied to a good meal, a favorable outcome, a beat, a timely insight, an admired performance, or life in a balanced state.” (Kempton 394). 
Sly Stone meets an Afro-Kabuki Warrior. Pierrot meets a Pimp. They wear found shirts as headscarves and as flags; carry branches from the dying trees found along the avenue as their walking sticks. They have holes in their pants. They are dirty. They have painted on themselves, on their faces and chests like children do, playing in their mothers' make-up. They have marked themselves with mud and clay as their paint, like warriors do. Before Kiss, before Iron J ohn, they have returned to the land of makebelieve and to the lost feminine with serious intention - at stake, their own freedom. They have returned to this city park to funk, and, as the lyrics tell us, "to hear their Mama call." (George Clinton once said, "Funk can save your life." And so can listening to your Mama.)

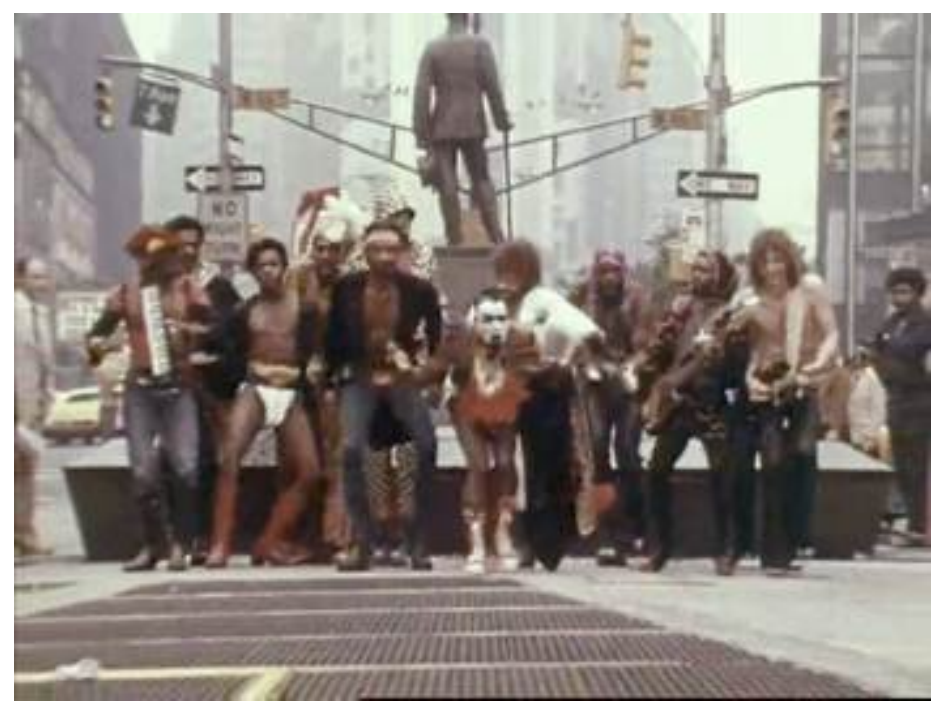

What do we make of the fact that this dance of masculine dreaming, of freedom and future and found community, is all to a song of lost women, mothers whose smiles mask that "life is really tough"? The singer remembers his mother, and the things that he as a child is not supposed to know - that she had to "turn tricks" in the neighborhood, in order to hold things together:

She was well known through the ghetto

Tricks would come and then they'd go

The neighbors would talk and call her J ezebel

But always with a smile, she was sure to try to hide The fact from us that she was catching hell, hey!

As the men seek solace in the beat, and in the sloppiness of the cosmos, their future mixes with things and people left behind, found objects and the lessons they never wanted to 
receive. As they seek rebirth, they are haunted by their mothers' grief:

\author{
Late at night I hear her call \\ Oh, lord, lord, I hear her call. \\ She said, "Father, father it's for the kids (Ahhh, \\ ahh-ah-ahhhh) \\ Any and every thing I did \\ Please, please don'tjudge me too strong."
}

The song is a series of countergrooves: the heavy down beat of the One, played by drum set and bass, countered by the extending riffs of the bongos; the high sobbing of Worrell's lead guitar, vs. the gruff, tight forward shuffle of the rhythm guitar; Gary Shider's earnest falsetto and street realism of his leading lyrics, countered by the mystical "Hoo Ha ha" of the chorus, a mystical dance with the devil. The psychedelic aspects of the song: the mystical chanting, the fuzzy blur of the guitar's tone, the deep hypnotic repeating of the One, might invite us inward, as Shider seems to be, possessed by the spirit of his mother. But ultimately, the song keeps bringing us back to the present, to the experience in our bodies of the beat, right now. In "Cosmic Slop" we hear performed in the lyrics and in the sound the lesson that will be revisited again and again by P-Funk: an acknowledgement of the complexity of desires, the funk in fucking: "And then the devil sang,/ would you like to dance with me?/ We're doing the Cosmic Slop." This is a song of empathy, a song of vulnerability, with a dance of yearning and flight. It is haunting and entails an exorcism of judgment. The voice of mother becomes woman, which becomes the self.

In this dance, in this cross-gender joining, they take pleasure in the movements of all of their parts. Polymorphously perverse, their pleasure is in the call of mother as it is in the join of skin to fabric; in the mystery of the mask; in the couching, the shimmies, the swing, the pop; in the move of air through nostrils from dank to clean and then funky again; in the peal of the guitar; in the heat of other men; in the dance of other men; in being watched, in dancing alone; in nature, in the confines of man-made concrete. In the fetish of leathers, headbands and feathers, in a cold metal saxophone on bare chest. In the One, in bass and drumbeat matching the beat of the heart, in blood rising and insistent. In the hush of cymbals and the chant of the singers; in the mystery, raising the hair on the back of the arms; and yes, in the crying of the man who in his falsetto becomes the voice of Mother, a pain in the solar 
plexus, the tear in it so much like her or your own voice, for that matter, when you wake yourself from dreaming.

$* * *$

"Cosmic Slop" appears in 1973, which is early in the life of George Clinton's collective Funkadelic. Clinton's first group, the Parliaments, a successful all-male doo-wop group sometimes taken with performing by the end of gigs pregnant and "in titties and wigs,"2 evolved into two entities, Parliament and Funkadelic in the 1970's and kept going until the early 1980's. These groups moved from underground sensation-performing in local clubs in Detroit, producing the edgy music that most radio stations were afraid to play - to become one of the most influential forces in black sound and performance-including huge, sold out highly theatrical stage shows. In their innovative oddity, P-Funk's songs became the bedrock of the hip-hop aesthetic, sampled by Snoop Doggy Dog, Run DMC, NWA, De La Soul, Digital Underground, Public Enemy, Dr. Dre, L.L Cool J ., and OutKast, to name only a few. ${ }^{3}$ They have also influenced other genre-and sometimes gender-

${ }^{2}$ George Clinton, in For the Record: George Clinton and P-Funk: An Oral History, edited by David Marsh (New York: Avon Books), 1998, page 8.

${ }^{3}$ In the music of OutKast, we see the strong influence of Parliament Funkadelic in their use of psychedelic and rock as well as funk, in their carnivalesque stage performances and sexually playful lyrics. Andre 3000 has cited Funkadelic's “Maggot Brain” as one of his biggest musical influences. He has even been spotted wearing a diaper on stage, like Gary Shider. I argue that while OutKast has the sartorial and musical playfulness of George Clinton, they differ in their business sense, and in their commitment to the truly funky, found/dirty/ grimy fashion of the earlier group. In many ways, P-Funk courts a kind of improvisational style - a bit of "countriness" that is not afraid to show its seams. (Here, I'm thinking of a parallel to Jose Munoz's discussion of Vaginal Cream Davis's embrace of "Countriness," as discussed in Disidentifications). Andre 3000, on the other hand, openly embraces a slicker entrepreneurial spirit - see for example, his luxury clothing line, "Benjamin Bixby." Thanks to Deborah Elizabeth Whaley for her suggestions on the OutKast/P-Funk connection. 
bending artists, including most notably Prince, Living Colour, Fishbone and the Red Hot Chili Peppers. Under the artistic direction of Clinton, Parliament and Funkadelic shared and swapped musicians, representing the yin and the yang of post-soul aesthetics. If Parliament became more associated with black music's commercial side, including dance and disco, Funkadelic was the voice and body of critique of the commercial. Funkadelic has been characterized by its critics and by Clinton himself as the more hard-rocking of the two projects, more driven by the experimental sounds of psychedelia and with Clinton's genre-pushing vision of a black music that re-embraces rock as one of its own - as the heat left out in black music's re-cooking of the blues by Motown and other, more commercial black music ventures. Together they form a complex relationship to the commercial and mainstream, critical of the music industries' tendency to eat its young, reflective of the history that has already shaped black music and the black bodies that produced it, but also pushing to create sounds to capture more ears. ${ }^{4}$ The bands evolved into several entities, including "Bootsy Collins and his Rubber Band," "The Brides of Funkenstein," and the "Parlets." And Clinton, Collins and some others of the band still play their three-hour sets in venues like Lollapolooza and the Pitchfork Festival as "The P-Funk All Stars." (Here, unless speaking specifically about one of the groups, I will refer to the groups collectively as Parliament-Funkadelic, or as "P-Funk".)

\section{P-Funk's "Black Militant Kind of Wierdness" - Disorienting Nationalism's Divisional Gender Logic}

In the song" Cosmic Slop," as with many others of PFunk's songs, we see at work a process of political and aesthetic reconfiguration, taking stories and aesthetics

${ }^{4}$ According to Dean Rudland's liner notes to the 2005 reissue of Cosmic Slop, for many in the band, including lead singer Gary Shider, Cosmic Slop attempted to a more commercial departure from the earlier Maggot Brain and America Eats its Young. Shider recalls that the song "Cosmic Slop" was a big hit in Washington, DC, and that there was even a dance to it, though the single released as a 45 , never made the charts. 
from black ghetto culture, ${ }^{5}$ and also braiding them with other influences, ultimately transforming what is considered "authentic" black culture, especially in the wake of Black Nationalism and the Black Arts movement. “Cosmic Slop" unapologetically combines elements of avant-garde and psychedelic rock culture with the existential, historical and aesthetic aspects of black working class life. It combines the hard guitars of white rockers like Vanilla Fudge and the pre-punk of Iggy and the MC5 (friends and co-conspirators with Clinton), or the exploratory openness of psychedelia, with the driving rhythm of J ames Brown, as well as the soulful falsetto of a Curtis Mayfield or Marvin Gaye. The film for "Cosmic Slop," produced for the album's release by Westbound Records, might be said to be informed by the Happenings and be-ins of the 1960's, and perhaps the experimental theater of Augusto Baol-particularly in Baol's attention, through theater, to the politics of bodies in space. Yet, as the song's lyrics concern black tribe, nation, and family, the realism of poverty and the sex trade, we might consider the influence of the Black Arts Movement in its interest in creating politicized art about black life. In its exploration of black clothing, hair and gesture, as well as urban cityscapes, I also see echoes of blaxploitation films of the

\footnotetext{
${ }^{5}$ Funk scholar Amy Wright notes the centrality of identification with working class blackness in P-Funk's music, in her essay, "A Philosophy of Funk: The Politics and Pleasure of a Parliamentfunkadelicment Thang!” in The Funk Era and Beyond: New Perspectives on Black Popular Culture, edited by Tony Bolden (New York: Palgrave MacMillan, 2008) pages 33-50. Wright argues that P-Funk's vision of "individual and collective freedom and equality" linked spirituality, sci-fi images, and psychedelia, with a world-view privileging black working class experiences. She points to the song, "What is Soul," which she says "celebrates images typically associated with poor blacks, defining soul as 'a hamhock in your Cornflakes,' 'rusty ankles and ashy kneecaps,' 'chiltlins foo yung,' and finally, 'you baby.' She argues that the band's message of black working-class pride challenged government officials and social scientists such as Daniel Patrick Moynihan, "who had deemed blacks a 'pathological' 'underclass' trapped in a 'cycle of poverty' that resulted from this population's values and behaviors” (Wright 38).
} 
same period, too. Yet rather than creating a glamorization of black street life, P-Funk definitely lets loose the weirdness and the unexpected. The terrain is never what one would expect from watching Superfly. The album Cosmic Slop presents a series of eclectic references and layered identities in its lyrics, from the neighborhood prostitute who is also a mother in the song "Cosmic Slop" to a new lover who might be a transvestite in the song "No Compute." This particular album's sound and lyrics shift wildly in tone, from soul-aching to wickedly sly to surreal.

P-Funk's embrace of outsized, 'funky' expressions of desire, its subcultural reference points as well as its bringing together of cross-racial artistic aesthetics might be one reason that the band in its first years had trouble securing stable airplay on black radio stations. P-Funk album cover artist Ronald "Stozo" Edwards talks about the group's difficulty to attract black audiences in its early days:

Niggas have always been a little scared of Funkadelic. My cousin bought that Maggot Brain album, it was the scariest shit I had ever heard. You had to be, like, a freak to be into them. It was the same trip with niggas likingJ imi Hendrix. It was almost a sellout to be into anything that had too much rock-and-roll guitar going on. Plus funk was still a bad word. If a mug was 'funky,' niggas would call you out on that shit. I'm not talking about the music, I'm talking about the odor. So there was just a select crew of some whites, but predominantly some blacks, who were willing to take that walk on the wild side (Marsh 73).

P-Funk's sometimes hard rock sound, combined with its challenge to political and cultural orthodoxies set it apart from much of the soul and funk of the period. Song writing partner Sidney Barnes describes the early band as having "a young, black militant kind of weirdness that people just weren't associating themselves with" (Marsh 40). The very kinds of experimentation that P-Funk trafficked in, and in particular, the melding of black nationalist and black hippy worlds, were sometimes thought to be socially and artistically dangerous, especially in their fluidity, at least by some in the Black Arts movement. Take for example, poet Haki Madhubuti's castigation of the black hippy, Clean, in his poem "Move Un-Noticed to be Noticed; A Nationhood Poem":

Clean, $\mathrm{u}$ is the first black hippy I've ever met. Why you bes dressen so funny, anyhow huh? 
I mean, is that $\mathrm{u}$, Clean?

Why u bes dressen like an airplane, can you fly, I mean,

Will yr/ bluejim shoes fly u,/ \& what about yr/ tailor made bell bottoms, Clean? Can they Lift $u$ above madness,/ turn $u$ into the right direction. \& that red and pink scarf around yr/ Neck what's that for, / Clean,/ huhn? Will it help you fly, yea, swing, siwinging swing (Quoted in Harper 197).

Madhubuti's poem paints a portrait of the black hippy as one who has abandoned proper blackness - and, by extension, himself. The poem's coyjabs at Clean's tailored bell-bottoms and pink and red scarf imply his refusal of proper gender, as well. Philip Brian Harper suggests that some of the poems of the black power movement depend on a "divisional logic" that betrays an anxiety about ambiguous gender identities. This binary is exemplified by an "authentic" model of black masculinity including selfdetermination, righteousness, black identification, and, hardness, on the one hand, and on the other, a "failed" masculinity: assimilationist, effeminate, mixed-up, too influenced by the standards of white culture-what Eldridge Cleaver describes in Soul on Ice as being "fucked." 6 This surveillance of sexuality and gender

${ }^{6}$ In his essay “Tearing the Goat's Flesh,” Robert ReidPharr speaks to the terror for Cleaver and others represented by the black gay male subject, in his ability to give voice to the larger idea that black masculinity in U.S. conceptions is conceptually queer. Pharr writes, "black gay men represent in modern American literature the reality that there is no normal blackness, no normal masculinity to which the black subject, American or otherwise, might refer. Indeed, Orlando Patterson, Henry Louise Gates, and Paul Gilroy, among others, have argued that the black has been conceptualized in modern (slave) culture as an inchoate, irrational nonsubject, as the chaos that both defines and threatens the borders of logic, individuality, [and] and basic subjectivity. In that schema, all blacks become interchangeable, creating among the population a sort of continual restlessness, a terror.” (Reid-Pharr, in Black Gay Man 103). I argue that P-Funk's play with gender norms takes this moment of inchoateness and runs with it, pushes it forward as a space of imaginative freedom. 
conflates body politics and desires with political vision, so that, for example, Baraka's "Civil Rights Poem" calls Roy Wilkins, "an eternal faggot"- perhaps by suggestion, because of his perceived assimilationist politics.

This policing of black masculinity by some in the Black Arts Movement had a lasting effect on ongoing discourse of black nationhood, authenticity, gender and sexuality. Black Feminist theorist Barbara Smith has commented on her own experiences of some of these constrictions of gender and sexuality in her introduction to Home Girls:

I will never forget the period of Black nationalism, power and pride which, despite its benefits, had a stranglehold on our identities. A blueprint was made for being Black and Lord help you if you deviated in the slightest way. How relieved we were to find, as our awareness increased and our own Black women's movement grew, that we were not crazy, that the brothers had in fact created a sex-biased definition of "Blackness" that served only them. And yet, in finding each other, some of us have fallen into the same pattern - have decided that if a sister doesn't dress like me, talk like me, walk like me, and even sleep like me, then she's not really a sister. Conformity. (Smith, Home Girls xi).

These tensions within nationalist black political movements around sexual and gender codes become particularly vexed in the context of art-making and performance in particular -- perhaps because poetry, music and other forms of performance are so emotionally powerful -- at the same time that some nationalist writers have feared performance as being politically diffuse. For example, in his highly influential book, The Crisis of the Negro Intellectual (1967), Harold Cruse betrays a growing discomfort with art, and particularly performance as a reliable medium of black politics. Though Cruse repeatedly embraces the creative intellectual as vital to the black community, and talks about his own experience in theater as the first place where he realized the potential for community, he distrusts the radical potential of nonlinear thinking, and the importance of feeling and other often ambiguous or fluid ways of knowing that accompany creative work. For example, Cruse gives Langston Hughes faint praise for his "extraordinary faculty for defining the confused sensations that constitute the collective conscience of simple minds," but adds that Hughes is "not a thinker" (Cruse 33). He says that J ames Baldwin fails to address "black reality" (Cruse 196) in his novels. In his 
commentary on Paul Robseon, Cruse reveals his discomfort with performance and its accompanying forms of feeling as knowledge and as the site of intellectual work:

[Robeson] exists in a world of illusion and there is little dividing line between his relationships with the world behind the footlights and the world of living reality. As an actor-performer, it was remarkable that Paul Robeson essayed an actual leadership role. But he never was to escape, fully, the world of make-believe. (Cruse 298)

Overall, Cruse suggests that because the performer's work is inherently and physically collaborative, "he is in many ways the most ethnically unstable, or the most aracial of all Negro artists" (Cruse 297). The actor must embody and interpret with others. Cruse here seems especially concerned about the performing body as open, making physical his suspicions about the ambiguity and potential vulnerability of the act of interpretation that also reveals itself in his discussion of Hughes. It would seem that for Cruse, the body, sensation, feeling, and cross-racial collaboration are dangerous as sites for intellectual work because of their unpredictability and lack of pure or stable answers to political problems.

P-Funk was often willing to explore black experience, particularly bodily, sexual and sensual experience at these points of ambiguity, vulnerability, pain, desire, and laughter, using tools of music that spoke to bodies individually and internally, as well as collectively. Yet this power to harness emotionally strong and sometimes inchoate feeling had a powerful effect on its listenersprompting some to find unity and empathy with other black men. Take for example P-Funk lead guitarist DeWayne "Blackbird" McKnight's description of Eddie Hazel's guitar on Maggot Brain:

I was listening to Funkadelic for as long as I can remember. 'Maggot Brain' fucked me up. It was emotion - the sounds that Eddie was making, and the way he was playing the notes that he played. I don't know where he was at the time he was doing it, but damn! That's what I think got me- just emotion-wise. I don't think I had heard a song like that with, like, no drums, no bass, and playing like that. (Marsh 45)

Hazel's guitar models a kind of vulnerability, emotional immediacy and transformation that is the nexus for a new form of community between the black men-and others 
who listen. As I will discuss below, in every day acts like hanging out and listening to the radio, record collecting and exchanging, going to concerts, or learning and imitating Hazel's guitar solos, black men have found powerful routes of transformation.

The black hippydom and funk experimentation of $\mathrm{P}$ Funk transgressed boundaries of black culture and sound, as well as sexuality and black respectability. George Clinton, as a kind of trickster figure, deliberately courts images that risk abjection and rejection. Clinton's recounting of his experience of the 1967 race riots in Plainsfield, NJ - a narrative that one might expect could be the place to solidify one's political status in the black community -- is playfully contrary, countering an idealized view of the properly masculine, properly righteous black nationalist warrior:

We couldn't get in or out of Plainfield for a while. They let us in, and we ended up in our apartment for the next two days. And like everyone else, you ran around and got whatever was laying out in the street. The only thing I tried to take was big boxes of tissues and sanitary napkins. My stealing days or my riot wasn't that profitable." (Marsh 23-24)

Here, as well as elsewhere, Clinton identifies himself not only with femininity, but abject femininity. In interviews, in public appearances, and onstage, Clinton and other band members risk the notion of proper black masculinity. They did so not only by cross-dressing, but also by playing with dynamics of humiliation, abjection and exposure. They would wear diapers or soiled bed sheets for robes, or, seethrough women's black lace panties with male genitalia showing through; or they would create the outsized and sexually anxious persona Sir Nose, with his pale, floppy, rubberized (and somewhat thinly) phallic schnoz for example - to disorient prevailing views of black masculinity and to open up new spaces for creation. Whether in Hazel's open displays of emotion or Clinton's self-parodic, shameshedding laughter, P-Funk's performances embody and embrace nonnormative forms of desire, and rage, as well as the unspoken loss that punctuates black male histories of embodiment in public space. ${ }^{7}$ In P-Funk's performances of

7 See Patricia Williams, "Meditations on Masculinities" Callaloo Vol. 19, number 4, Fall, 1996, pages 814-822. Williams here meditates on journalist Brent Staples' description in his memoir Parallel Time of his coping 
eccentricity, and especially gender and sexual eccentricity, we might find a project of "creative historical knowing," to use Katherine Bond Stockton's phrase (Stockton 24), that exposes among other things, the racist logics of social debasement.

This disorientation, as a form of disidentification, can have critical as well as pleasurable effects. As J ohn Corbett suggests, P-Funk's disruptive, disorienting take on black masculinity, shares with other black eccentric musicians Sun Ra and Lee "Scratch" Perry, strategic use of alter-egos and personal mythologies in their performances to support an overall aesthetic and politic of disorientation or "unreality."8 Whether we look at George Clinton's elaborate staging of "The Mothership Connection" complete with rebirth from an onstage pod, or the comic book struggles of good and evil between Sir Nose and Dr. Funkenstein, Clinton and P-Funk embrace the unreal as a space of critique. Disorientation is not just a moment of confusion; it is a moment of performative command to look at the world in a decentered way- indeed to embrace a

strategy of "Scattering the Pigeons"-watching and laughing as fearful white couples scatter to opposite parts of the sidewalk, when he fails to cross the street or step aside. Williams laments, "The gentle journalist who stands on the street corner and howls. What upsidedown craziness, this paradoxical logic of having to debase oneself in order to retrieve one's sanity in this remaindered marketplace" (Williams 816). This "Scattering the Pigeons" game becomes a touchstone for queer black male critic E. Patrick Johnson as well in his stage show "Strange Fruit." (E. Patrick Johnson, "Strange Fruit: A Performance about Identity Politics.” TDR: The Drama Review, Volume 47, Number 2 (T 178), Summer 2003, pp. 88-116.)

${ }^{8}$ See John Corbett's comparative analysis of Clinton, Sun$\mathrm{Ra}$ and Perry and their strategic embrace of "disorientation" in his chapter, "Brother from Another Planet: The Space Madness of Lee 'Scratch Perry, Sun Ra, and George Clinton,” in Extended Play, pages 7-25. Corbett says that all three share an iconography built on an image of disorientation, which then becomes a space to critique social marginalization: "Staking their claim on this ec-centric margin - a place that simultaneously eludes and frightens the oppressive, centered subjectivity - the three of them reconstitute it as a space of creation” (Corbett 18). 
constant position of critique and dis-ease. Clinton not only asks his listeners to disorient themselves from normative modes of pleasure; he presents disorientation itself as a form of pleasure. This embrace of disorientation will become the fuel for transportation to new worlds in the futurist and gender-bending work of Me'Shell Ngeceocello. Both artists ask their audiences to see and hear freshly through forms of beautiful confusion, in the process expanding the spaces of black identity.

P-Funk's performative reconfiguration of normative black sexuality, as well as its nonessentialized rethinking of gender and nation, contradict, at least some tenants of black sexuality in nationalist rhetoric of this period. If, in the Black Arts movement and in black-nationalist rhetoric, we see the solidification of a particular kind of heterosexual black manhood, and the importance of art in policing that notion of black manhood, P-Funk then complicates matters, even as it presents its own rhetoric of a populist nation. Here, the nation is formed not specifically by race, but by "One Nation Under a Groove." Their nation is founded on the love of funk, a form that Clinton and P-Funk explicitly link to black musical and cultural forms, which draws from the call and response of gospel, ${ }^{9}$ the bent notes of slave calls, African polyrhythms, and the soulful harmonies of doo-whop. This nation also relies on the street storytelling of black life; "groove" is something that anyone, guided by funk, potentially can enter, "just for the funk of it."10 Nation, under the P-Funk

${ }^{9}$ George Clinton once said, "Soul is from Church. But funk came from the people who didn't have enough money to buy shoes to go to church, and had to work on Sunday." (Tony Green, “Tracing Funk’s Sources” St. Petersburg Times (FL), November $27^{\text {th }}$, 1994, page $1 F$.)

${ }^{10}$ These references are deep within the DNA of P-funk's music, but George Clinton explicitly references the importance of recognizing funk's deep roots in black culture in the face of the pressures of crossover on his 1986 satiric solo album, R \& B Skeletons in the Closet. When interviewed about the album Clinton comments, "In order to have that crossover appeal, the companies tell the artists to use less bass or don't say the word "funk" or something like that. So you can get played on pop radio. Once you do that to sell all those records you start gearing your music for that market. Before you know it, all the R \& B that you 
banner of groove, is culturally specific and fluid; it is embodiment and invites transcendence. Such rethinking of nation as new potentiality, constructed by desire ("Do you promise to funk, the whole funk, and nothing but the funk?")--is reflected in Eve Zibart's description of "The Chocolate J am," an all-day celebration of music and black pride that took place in Washington D.C. in J uly of 1978, and which featured the music of P-Funk and Bootsy Collins as headliners:

The dark heads and bright clothes of 10,000 young Washingtonians on the field of RFK Stadium break into the fragmentation of a vast Impressionist painting. A simmering effect over the surface gradually resolves itself into the bobbing groups of tightly packed dancers and the shaking of thousands of upraised arms. Driven by the insistence of the disco beat, couples bump hips, knees and elbows; on the edge of a giant platform, a roadie dances in exact tandem with a girl 10 feet below. (Zibart B1).

Here, we see Funk's potential to unite its audience precisely in the experience of disorientation. ${ }^{11}$ As Clinton and Hazel tell us in their 1970 song, "Free your mind and your ass will follow."

\section{Queering P-Funk: Music as a Space of Nonnormative Black Self-Fashioning}

The musical space of P-Funk-whether it is the space of the live concert or the space between your ears or headphones - exists as an important space for improvising and performing nonnormative sexual desires for black men. Although these moments are at times inchoate and

had in you is completely hidden." (Clinton quoted in a review by Robert Palmer, “The Pop Life: Clinton's Satire has a Bite,” The New York Times, May 7, 1986, section c, page 26.)

${ }^{11}$ P-Funk's melding of funk and psychedelia could also have a disquieting effect on normative notions of black nationhood. In Turn on Your Mind, Jim DeRogotis characterizes psychedelic sound as including often ambivalent, playful lyrics, and a sound which brings "a loss of ego or depersonalization and sense of physical connection to everything one sears or hears" (DeRogotis 11). 
contradictory in terms of a critique of sexism and homophobia, they do at least advance an "elsewhere"-a fantasy space for new formations of self. If we can look beyond the rhetorics of unity and racial uplift, which tend to flatten sexual identities, we might well find more examples where seemingly normative male spaces serve as places for more fluid sexual and gender self-fashioning, identification and desire. We might think of music as this space-sometimes a space within a space tightly patrolled by others.

While black feminists, gays and lesbians have--perhaps by necessity--created a visible public space to talk about and practice nonnormative sexuality and community, such a community space for nonnormative heterosexual black men is missing. Here, I am thinking of the formation of nonnormative sexual communities through clubs and other social spaces, the founding of feminist and queer journals and other publications, and political activist movements. Where are the spaces for black men who are heterosexual to talk about their desires -- particularly nonreproductive sexual desires-- and to claim public space to talk to each other about those desires? If, as many have argued, the black family is the space to be productive citizens, ${ }^{12}$ where are the spaces to be nonproductive? I argue that we have to look with a queer eye at the narratives, creative practices and performances of black masculinity otherwise deemed "normative," looking in high school halls, straight bars, and spaces for style and self-fashioning, like barbershops. Interestingly enough, George Clinton's memories about his first job in the Silk Palace as a hair stylist, in a Newark, NewJ ersey Barbershop, gives a very different construction of this mostly male space that we see in the dominant media. If in films like Ice Cube's Barbershop, we see the Barbershop as a space where playing the dozens, hair styling, and even physical violence allow men to keep each other "in check" about their masculinity, Clinton's descriptions of the over

\footnotetext{
${ }^{12}$ For a cogent analyses of black manhood, gender and heterosexuality, see Mark Anthony Neal, New Black Man (New York: Routledge, 2006), Athena Mutua's collection, Progressive Black Masculinities (New York: Routledge, 2006), Donald Byrd and Beverly Guy-Sheftall's Traps: African American Men on Gender and Sexuality (Indiana University Press, 2001), and Philip Brian Harper's Are We Not Men (New York: Oxford University Press, 1996).
} 
and underground economies at the Silk Palace hint at a more chaotic and perhaps layered and fluid space of male self-fashioning, and pleasure:

Processing hair. We had two or three older barbers who had their clientele, playing checkers and shit. Then we had the younger guys, who may be nodding, you know what I mean? I might have a girl in the back there. Somebody's head might be burning, talkin' bout "Get this shit out of my muhfuckin' head?" Congolene-fry that muthafucka! J ust put it on your head with a comb or brush, grease your head to death, then wash your head out while you pat your feet and holler. Or you might get: "I'm going to audition for my record thang, I'll tell my boy to comb you out. I put the waves in, so you gon' be cool." (in Marsh 10)

Clinton's Barbershop here is a real space: a particular and indexible place in a particular historical moment located in the black community in Newark, New J ersey, and linked to the other Chocolate Cities that P-Funk sing about: Washington, D.C., New York City, Cincinnati and Detroit-as well as an imaginative space of laughter and experimentation.

To locate P-Funk in a queered discourse of eccentricity requires listening for what is unnamed, unrecognized, and perhaps unclaimed - what Phillip Brian Harper calls "Critical speculative knowledge"13 of what seems to be hiding in plain sight: "For how else can you capture a boogie, if you don't attack from the back?" (from P-Funk's "Theme to the Black Hole"). P-Funk's spectacularly freaky funk, its enthusiasm for booties, and its almost Iriguraian ${ }^{14}$

${ }^{13}$ See Phillip Brian Harper's 'The Evidence of Felt Intuition: Minority Experience, Everyday Life, and Critical Speculative Knowledge" in Queer Black Studies (Duke University Press, 2005) page 106-123.

${ }^{14}$ I hear echoes in Clinton's fantasy of aquaboogieing and Luce Irigaray's description of women's diffuse sexual pleasure and logics in This Sex Which is Not One (Ithaca: Cornell University Press, 1985):

She experiences pleasure almost everywhere. . . the geography of her pleasure is much more diversified, more multiple in its differences, more complex, more subtle. 
call to surrender to the pleasures of underwater aquaboogieing seem to these eyes as queer as it gets. Kodwo Eshun, Ricky Vincent, and Anne Danielsen discuss the erotic pull of P-Funk's music, but have less to say about the implications of their eroticism in terms of gender codes of black masculinity. ${ }^{15}$ A queered reading of P-Funk goes

(quoted in Ann Rosalind Jones, "Writing the Body: Toward an Understanding of l'Ecriture Feminine,” Feminisms: An Anthology of Literary Theory and Criticism (New Brunswick, NJ: Rutgers University Press, 1997) page 372).

${ }^{15}$ I owe much inspiration from Kodwo Eshun's writing on P-Funk's instrumentality and the music's effects on our relationship to our bodies in More Brilliant than the Sun: Adventures in Sonic Fiction (London: Quartet Books, 1998). Eshun captures the erotics of abduction in P-Funk's Clones of Doctor Frankenstein, where he says that

P-Funk compels you to succumb to the inhuman, to be abducted and love it. Funk gets drawn out of the body, an entelechy harvested by an alien force. . . P-Funk is the gladallover suffusion of Funkentelechy, the enjoyment of mutation. Instead of resisting alien extraction, dancing turns it into a gift, turns onto the joy of being abducted (Eshun 14).

Rickey Vincent's definitive chapter on the P-Funk empire in Funk: The Music, The People, and the Rhythm of the One takes some time to note the disconcerting sexiness of Bootsy Collins's music, as an important contribution to the band. He calls the period that Bootsy and Rubber Band joined the P-Funk empire, "the nastayest and most liberated form of P-Funk, symbolically the exposed genitals of the P-Funk vibe.” In Vincent's description, in songs like "Munchies for your Love," Collins combines "a giddy, childlike geepiness" with the "orgiastic bass effects" of "an erotic troubadour”-certainly an eccentric combination. Ann Danielsen's Presence and Pleasure: the Funk Grooves of James Brown and Parliament takes an ethnomusicological approach to beats, time and pleasure in P-Funk's music. In "A Philosophy of P-Funk: The Politics of Pleasure of a Parliafunkadelicment Thang,” Amy Phelps discusses the band's sexual politics post-sexual revolution. But these writers don't discuss the implications of P- 
against the grain of much recent cultural criticism and music criticism, which has been primarily focused on PFunk as a place to imagine an Afrofuturistic Utopia (or Dystopia); ${ }^{16}$ or P-Funk's interventions in politics of sampling, copyright and other aspects of black cultural traffic. ${ }^{17}$

A queered reading of P-Funk faces the strong sense of ownership of the band by (straight) fans, blogs and other commentary. Perhaps this is because P-Funk's rhythms have, especially in this hip-hop age, become the gold standard of (heterosexual) black male cool. We see the

Funk's experimentations with gender for their constructions of pleasure.

${ }^{16}$ On Parliament Funkadelic's Afrofuturism, and the politics of black utopia or dystopia in the music, see Kodwo Eshun's More Brilliant Than the Sun: Adventures in Sonic Fiction. (London: Quartet Books, 1998) especially pages 53-54 - and "Further Considerations of Afrofuturism” in CR: The New Centennial Review. Vol 3, no. 2, 2003, pages 287-402. John Corbett, Extended Play: Sounding Off from John Cage to Dr. Funkenstein (Durham: Duke University Press, 1994), pages 7-24; Paul Gilroy’s brief discussion in The Black Atlantic: Modernity and Double-Consciousness (Cambridge: Harvard University Press, 1993) pages 202-203; Mark Anthony Neal's What the Music Said: Black Popular Music and Black Public Culture (New York: Routledge, 1999), 102-103; Michael Ladd, "Staring at the Cosmic Slop: The Mothership Connection between Triple and Quadruple Consciousness" (in Rip it up: Black Experience in Rock ' $n$ ' Roll, edited by Kandia Crazy Horse (New York: Palgrave MacMillan, 2004) 71-84.

${ }^{17}$ On P-Funk, techno and automation, see George Lipsitz, Footsteps on the Dark: The Hidden Histories of Popular Music (Minneapolis: Minnesota University Press, 2007) pages 240; 245-245; Andrew Bartlett, “Airshafts, Loudspeakers, and the Hip Hop Sample: Context and African American Musical Aesthetics,” That's the Joint! The Hip-Hop Studies Reader Reader in passing page 399; Arthur Kempton, Boogaloo, pages 382-414. Clinton's legal cases against copyright violations and sampling has been profiled in the recent documentary Copyright Criminals (2008), dir. Benjamin Franzen). 
power of P-Funk as a sign of cool and black male normativity in cultural critic Robin D.G. Kelley's autobiographical essay, "Confessions of a Nice Negro or Why I Shaved My Head," where he claims Funkadelic as important to his own Post-soul-and insistently non-nerdy coming of age in the 1980's:

Never an egghead or a dork, as a teenager I was pretty cool. I did the house-party circuit on Friday and Saturday nights and used to stroll down the block toting the serious Radio Raheem boombox . . .Those of us who had cars (we called them hoopties or rides back in that day) spent our lunch hours and precious class time hanging out in the school parking lot, running down our Die Hards to pump up Cameo, Funkadelic, Grandmaster Flash from our car stereos. I sported dickies and Levis, picked up that gangsta stroll, and when the shag came in style I was with it-always armed with a silk scarf to ensure that my hair was laid. (Kelley 13-14)

But while Kelley includes listening to Funkadelic as one of the many initiation rites that mark his place in the world of black male cool, his description at the same time implicitly reveals how black male self-fashioning and performance have some room for fluidity in its appropriation of feminine gendered signs - certainly something explored by Cameo, as well as P-Funk. These standards of black male cool are not naturalized or stable: five or six years earlier, that silk scarf would label him a "black hippy" and a decade later the shag might well get him teased in the hall. While the costs of a "bad performance" of black masculinity can be high (to borrow E. Patrick J ohnson's notion, in his article and performance Strange Fruit) black masculinity can and does often have elements of the "silly" or "queer," if put in another context, or pushed into excess. ${ }^{18}$ As I

${ }^{18}$ Indeed, later in this essay, Kelley glances at but never quite engages the sometimes gender incongruity of black gangster style:

Some of the hardest brothas on my block in West Pasadena kept their perms in pink rollers and hairnets. It was not unusual to see young black men in public with curlers, tank-top undershirts, sweatpants, black mid-calf dress socks, and Stacey Adams shoes, hanging out on the corner or on the basketball court. And we all knew that these brothas were not to be messed with. (The rest of 
argue at more length later, P-Funk takes the inherent aspects of silliness/ excess in black male style and embraces it, pushing it to the edge. By exposing what is inherently queer about black male sexuality and style, P-Funk can show us what in other circumstances must be masked, or encoded in normative black male identity and performance. At its most fundamental level, in the music and live performances of Funkadelic and Parliament, we see a rejection of fear, loathing and shame of the black body and the embrace of sexual and imaginative freedom. ${ }^{19}$

The implications of P-Funk's work as potentially feminist and queer gets drowned out by the dominant conceptualization of funk as a stereotypically masculine sound and scene, including primary emphasis in some musicologists' working definitions of funk on The One, as opposed to what musicologist Anne Danielson calls the "extended ambiguity" of funk. ${ }^{20}$ Funk scenes locally and nationally have been dominated by men -- despite some

the world probably knows it by now, too, since black males in curlers are occasionally featured on 'Cops' and 'America's Most Wanted' as notorious drug dealers or heartless pimps.)

(Kelley, Speak My Name 15).

${ }^{19}$ Ultimately, I am thinking of Cathy Cohen's directive to reexamine queerness through the lens of nonnormative black heterosexuality in order to, as Cohen writes, "think about how we might construct a new political identity that is truly liberating, transformative, and inclusive of all those who stand on the outside of the dominant constructed dorm of state-sanctioned white middle-and-upper-class heterosexuality" (Cohen, "Punks, Bulldaggers, and Welfare Queens” 25).

${ }^{20}$ See Danielson's analysis of “Give up the Funk," page 122. While she doesn't offer a specifically gendered reading of funk performance, musicologist Anne Danielson usefully suggests that funk has been read uncritically as "primativist" sound, or "Body music" affirming a notion of a "pure blackness" that nonetheless overlooks the rhythmic complexities of the style. Such readings confirm the idea of black music as "unmediated bodily expression" and reduce the black body as merely sexual (in Presence and Pleasure: The Funk Grooves of James Brown and Parliament (Middletown, CT: Wesleyan University Press, 2006 pages $20-28)$. 
amazing examples of female musicianship in the funk scene, including Sly Stone's trumpeter Cynthia Brown, Labelle, Betty Davis, Female P-Funkers, the Brides of Funkenstein and the Parlets, M'shelle N'degeocello and others. ${ }^{21}$ Despite this, P-Funk's "militant kind of wierdness" makes room for a new and nonnormative masculinity. As George Clinton once told Rolling Stone Magazine, "Funk is anything that you need to be to save your life." 22

P-Funk through its sound, lyrics and use of theatricality on and off stage, makes room for a more exploratory and decentered notion of black male identity. I'm interested in the ways that we might think of a queer heterosexual black masculinity as a means of giving voice and visibility to black masculine self-fashioning that is often 'bred out' of the traditional neo-liberal subject. Cultural Historian Walcott suggests that narratives such as heteronormative conceptions of family, or the overall idea of the triumph of black men over slavery through economic achievement and traditional notions of power -- what he calls the "from victim to victor" narrative -- are often lobbied to root out less coherent, and ultimately, less economically useful notions of black masculinity. (This notion of black masculinity, according to a post-liberal state,was in formation in the United States during the "Post-Soul moment"). ${ }^{23}$ I'm particularly interested in the ways that P-funk might be read as an opposition voice in this context, presenting performances of black maleness that play "chicken" with codes of respectability.

As George Clinton takes some of the discourses already in the air, including psychedelia and Black Nationalism and makes them his own, he creates a space for something strange, outlandish, and new, particularly in terms of gender. Many fans and critics have praised and theorized

\footnotetext{
${ }^{21}$ On the gendered dynamics of local funk scenes, see Scot Brown, "A Land of Funk: Dayton Ohio" in The Funk Era and Beyond page 82. On women navigating the sexist and often homophobic worlds of funk, see Carmen Phelps, "Living the Funk: Lifestyle, Lyricism and Lessons in Modern and Contemporary Art of Black Women” The Funk Era and Beyond, pages 187-191.

${ }^{22}$ Quoted in Amy Wright p3.

${ }^{23}$ Rinaldo Walcott, "Reconstructing Manhood, or, The Drag of Black Masculinity: in Small Ax 13 (1), 75.
} 
Clinton's funk as a means of space travel - an important tenet of an "Afrofuturism" that nonetheless reminds us that we cannot escape our origins. As Michael Ladd says, "Funkadelic focused on flight, but not escape." (Ladd 74). Nevertheless, I think that there is room for more thought on how Clinton, Parliament, and Funkadelic make us think about this "something new" as a distinctly embodied experience.

Funk, with its hard-driving rhythm is very much about the body and about pleasure. As many recent theorists on Funk have written, you cannot have funk without the sweat, without the labor of the body at work (and play). Clinton asks us to think about the funky body as one that challenges the order of the ways that the body is patrolled and surveilled in space. In the song "Aquaboogie," for example, Clinton imagines an underwater escape from this history of control, where: "With the rhythm it takes to dance to what we have to live through/ you can dance underwater and not get wet." The song offers underwater as a place to speak back to history, to defy the rules of nature. Critics Tony Bolden and Cheryl L Keyes speak to the West African etymology of the word funk as meaning both "Bad odor" and "Bad order" - a tantalizing combination. ${ }^{24}$ Clinton and his Parliament Funkadelic crew are not just interested in outer space, but also in reconceiving inner spaces: the spaces of desire, and the performance of those desires for others, through the creation and sometimes deconstruction of "personas" of blackness. In performance, P-Funk commandeers the nightclub, the stadium arena, and or the city park, to perform sexual freedom and exploration outside of the familiar discourses of courtship and family.

In spite of the often crudely sexualized terms in which male and female relationships are represented lyrically and in terms of the icons of its covers, Parliament Funkadelic's ultimate vision of black humanity seems to be one in which men and women are equal and connected in struggle. This is captured well in Pedro Bell's cover for One Nation

\footnotetext{
${ }^{24}$ Tony Bolden, “Theorizing the Funk: An Introduction” The Funk Era and Beyond, edited by Tony Bolden (New York: Palgrave MacMillan, 2008) 13-29, especially pages 15-17; and Cheryl Keyes, "Funkin' with Bach: the Impact of Professor Longhair on Rock 'n' Roll” in The Funk Era and Beyond, edited by Tony Bolden (New York: Palgrave MacMillan, 2008) 213-226; especially pages 222-223.
} 
Under a Groove, where men and women plant a black nationalist flag together. P-Funk represents that struggle though, as an ongoing and imperfect one. Much of PFunk's album cover artwork provocatively represents black women's bodies as contested territories, and as the locus for political and psychic frustration. The cover for Cosmic Slop features an image of a naked, chained black woman that echoes some black nationalist art where the enslaved women become the icon for black struggle, or where the head or body of a nude black woman is used to depict a lost "Mother Africa." But these P-Funk images utilize a more dominant note of the surreal. The woman's left nipple is circled by a map of the U.S. and Latin America and the Caribbean; the nipple itself seeming to be the waters of the Caribbean. Her left breast has been transformed into a combination lock. These bodies are mediated objects, where scopophilia and touch are linked to colonization and capitalism. Rather than the nostalgic use of the black female body as a sign of lost Africa that we see in some popular Black Nationalist iconography, these images present the black female body still entangled in political battles and in the economic exploitation of others. The lettering on the album is punctuated with spurts of what seems to be representations of blood, sperm and/ or milk, linking the album's artistic production and creativity with the material products of the body and sex. On the cover of "Maggot Brain," the bodies of women even more actively express their frustration. Here, a woman, screaming and surrounded by maggots, becomes the icon of frustration and dis-ease explored in the songs -- the visual equivalent of Eddie Hazel's crying guitar in the song "Maggot Brain." In this way, the album features an image of collective frustration and struggle.

Yet these album covers do sometimes implicate P-Funk in their participation in the objectification of black women, and in the trade of sexualized black bodies that they would seem to be critiquing. The controversial cover for The Electric Spanking of War Babies skirts the line between critiquing and exploiting the objectification of women's bodies. The back of the album depicts a nude black woman (or cyborg?) on all fours, transformed into a machine in which money goes in and sound comes out. Her body is punctured with knobs, wires and bolts. The critique is somewhat ambiguous. Is she meant to be the personification of the exploitation of black people? A "tarbaby" produced by the powers that be to distract us all from our own exploitation? Is she a gullible customer? PFunk's placement of itself as an increasingly successful 
commercial band, straddling underground and mainstream success, is also unclear. In my reading, the cover seems to extend its critique of the institution of slavery to consider how the exploitation of black bodies and labor continues through the music industry -- perhaps here a not so veiled critique of commercialized black music such as that of Motown (the target of George Clinton's ire and critique). This reading is reinforced by the fact that the woman is shown shackled, and seems to fit an ongoing critique of the music industry as a form of exploitation of black labor leveled by Clinton and the group. Whatever its intention, the cover was boycotted by the group Women Against Pornography, and Warner Brothers forced the group to alter it. However, in a rebellious move against the company, P-Funk created a cover that allowed the viewer to peek at the shackled female legs, and bits of her torso, with slashes and slits, and the words, "Oh Look! The cover "they" were TOO SCARED to print! Peek Here. And Here, too." Perhaps this new "peepshow" cover is meant to suggest that WAP and Warner Brother's emphasis on the nudity overlooks the political critique of the original cover.

Many of P-Funk's songs explore the politics of relationships and sexual conquest, in wry, and sometimes self-critical ways. Male sexuality is often the source of gentle and not so gentle mockery and critique. Consider the nasally, weaselly, potentially parodic chorus to Clinton's otherwise pretty celebratory ode to "doggin"'” in "Atomic Dog": "Why must I be like that? Why must I chase the cat?/ Nothin' but the dog in me." 25 In the later Afrofuturistic concept albums of the mid-1970's and into the 1980's, including The Mothership Connection and The Clones of Dr. Funkenstein, the evil institutions of oppression are depicted as lunatically phallic: Sir Nose and his bop gun, the dookie squad who chases after its enemies with "pissgun rays" on the inside cover of One Nation Under a Groove. It is particularly significant that the

\footnotetext{
${ }^{25}$ Still, I suspect that any confessional aspect of the song is overshadowed by its sheer, lusty coolness. The song's hip rhythmic panting, deep-voiced "Dawg" and "bow wow wow yippee yay" has been sampled by an amazing number of artists, most notably Snoop Dogg's, in "Who Am I" In fact, this song has been sampled in over 50 songs, and was subject of a 2007 copyright lawsuit between Clinton and his former producers, Bridgeport (formally Westbound Records).
} 
group's constant return to and sometimes critical image of the pimp as both site of great style and cool and figure of economic oppression returns over the course of their work as a trouble-spot to negotiate. (See for example, the song "Trash A-Go Go" on the Cosmic Slop LP, which features a judge's shaming of a man who pimps his girlfriend to feed his drug habit). Rather than settle these moments of contradiction in black sexual politics and desire, the group embraces moments of ambiguity in black life. So according to "Funkadelic Bylaw No. 19: 'It is better to open your eyes and say you don't understand...than to close your eyes and say you don't believe" (credited to O.J . Rodney, on the cover of One Nation Under a Groove). In other words, according to P-Funk, it is better to acknowledge the complex and contradictory aspects of black love, sex and politics as they present themselves to you in the flesh, rather than to pretend you are beyond them. This is the hard-learned lesson taught to Sir Nose by Dr. Funkenstein, the persona created by Clinton and featured in songs like "Theme to the Black Hole," "Gloryhallastoopid" and "Flashlight." Sir Nose always claims that he is too cool to sweat, funk, swim or dance, until he is taken over by the music.

Clinton lends his skills in the theatrical to engage in an ongoing conversation about the mask of blackness, and in particular, the experience of double, triple and even quadruple consciousness. ${ }^{26}$ There is a pushing of this

${ }^{26}$ In his essay on quadruple consciousness and Funkadelic's Cosmic Slop in the context of U.S. imperialism, Michael C. Ladd writes that:

It can be argued that black Americans are the only four-dimensional people on the planet. Doubleconsciousness is whipped up and beat down in every essay; I maintain that triple consciousness is the view that black American has of him-or-herself in a neocolonial context. One examines one's self as an oppressed person of color who, in a "third world" context shares an imperialist position with whites of the United States. Ugly but true. A fourth consciousness, however, allows the black American to reinvent him-/ herself from space and therefore reaarange her/ his gaze to that of the ultimate outsider and simultaneously insider. A fourth consciousness allows one to bybass the other three. ... Fourth consciousness view exposes the 
conversation into a new form by Clinton, by getting us to think about such masks playfully. His is also the mask of the trickster. The mask is a burden and a boon, a way to escape, recreate oneself, and trip on out. The masks of trickster, space alien, and hippy allow for an exploration of the black imagination, and with it, gender and sexual freedom.

P-Funk does not posit as the solution to full humanity and black freedom the suppression of desires, in all of their sticky, complicated and funky forms. Instead, we are encouraged to dance our way out of our constrictions. PFunk chooses subversive and nonnormative tactics: crossdressing and transvestitism (from performing as a pregnant doowop group to the consideration of a mock marriage to Iggy Pop); scatology; ${ }^{27}$ fluid lyrical movements between male and female voice; and depiction of the fluidity between masculine and feminine desire; the melding of human and machine and sometimes with it, the fetishization of nonhuman objects as sites of desire (including a gyrating dance with a huge flashlight in a 1978 stageshow in Houston); the mind-expanding ethos (and sometime ingestion) of psychedelic drugs; the embrace of nonreproductive sexuality, and especially praise of the "booty" as site of desire (in "The Theme to the Black Hole"), and through it all, an embrace of Silliness as an aesthetic.

absurdidty of race and simultaneously continues to focus on the Diaspora. It runs the risk of slipping into universalism -'space people universal lover'but the tradition is deeply connected to home and the soul.

(Michael Ladd, "Hardcore Jollies in the Himalayas, Staring at the Cosmic Slop: The Mothership Connection between Triple and Quadruple Consciousness" in Rip it Up: the Black Experience in Rock ' $n$ ' Roll, edited by Kandia Crazy Horse (NY: Palgrave MacMillan, 2004) 79).

${ }^{27}$ Guardian critic Tom Cox wrote in 2000 that, "Clinton has probably never written a boy-meets-girl song in his life. Boy-meets-girl-and-offers-her-some-intergalactic- urine, maybe, but not boy-meets-girl (Tom Cox, "Funkenstein Lives: George Clinton is 60, but he’s as barmy as ever.” The Guardian (London). July 21, 2000, page 14. ) 


\section{Black Men, Black Cool and the Aesthetic of Silliness}

Anyone who has seen a photo of George Clinton himselfbursting wide-legged and smiling out of a spaceship on the cover of The Mothership Connection or more recently, pumping up the Lollapalooza crowd in a large African gown -- must be struck by Clinton's propensity toward outrageous, gender bending and original style: hair extensions (always at least shoulder length, and in unearthly colors: day-glow orange, acid green, or platinum blonde); his rocking of oversized sunglasses and hats (even before Flavor Flav thought of it) and willingness to switch from spandex and spangles, to long white ermine coat, to a wedding gown. These outfits are bricolage - Clinton might be wearing an African Dashiki combined with a raspberry beret covered in political buttons, under which he might be rocking a long blond wig. He might bring together a shiny pimp "cane" with silver thigh high platforms. Gary Shider, inexplicably, is almost always wearing a diaper. (And in a 1978 live performance in Houston, a diaper and silver leather chaps). The Brides of Funkenstein, the women of the group, sometimes are in everyday street wear, sometimes in the space-age glamour favored by Labelle, and other times, in what looks like their panties. During the Dr. Funkenstein era of the early 1980's, the Brides and Clinton himself wore "big booty" fat suits-referencing, perhaps, the Venus Hottentot. (See photo of J eanette McGruder with Boogie Mosson, 1979). At play seems to be a sampling of historical moments and influences and textures and most definitely genders. In interviews Clinton has reflected a strong interest in black style, and especially the creative and sometimes over the top impulse of black cool, especially after his experience as Barber and Hairstylist in NewJ ersey:
'After you've done other people's hair for so long you know the concept of doin' hair,' he says, wrapping a bright braid around his index finger. The garbage man looked just as cool as the pimp and the singer when they left the barbershop. Really, style is just a bunch of bullshit, it's just how you carry it. If you is safe with that concept, then you can be ugly as you wanna be or cool as you wanna be and know that neither of them mean shit! No matter how cool you are, you can go someplace where you look corny as hell to somebody...They thought that to have your doo was the corniest stuff in the world when you got 
around hippies. And then a few years later, the afros came out and then the black people started lookin' silly. So it means that styles just go 'round and 'round and ain't nothin' permanently cool or corny.' (quoted in Corbett 147)

Clinton's deconstruction of black style flies in the face of one of the beloved commandments of Soul: that black people are just naturally cool. Black style, then, and that accompanying command to be cool becomes freed up as a space for play, for silliness. As Doctor Funkenstein (with dripping white Ermine, hat, sunglasses and cane), Clinton captures the image of the pimp, but it gets transformed and transmogrified. Clinton takes what is already over the top, and pushes it further, shows us the potential queerness of it. Stepping out of the mothership, and surveying the crowd, he captures the hypervisibility and command of this image, but he further denormalizes it, lets us laugh, too. He gives the pimp a blond wig, puts Superfly together with Foxy Brown, and then some silver chaps from the Village People, to boot. He changes clothes and in so doing, he change places. His performance is for the people on the street and in the clubs; for white college girls and bourgie black men; for the black hippies who have always wanted to have a stage of their own. His performance is for Led Zeppelin (who apparently did go to their shows, too); for Berry Gordy to show him what he is missing; for Aretha and the music executives; for the white soul crooners learning black sound. If necessary, this performance might entail stripping off clothes. They would re-steal the sound -- their guitars and amps would create new, performative twists. ${ }^{28}$

${ }^{28}$ Original Funkdelic bassist William "Billy Bass” Nelson and George Clinton recall a particular moment of revenge on Berry Gordy and Motown, while Clinton was apparently on LSD:

Billy Bass: We found out that everybody from Motown was at that gig [at the twenty Grand in Detroit one Christmas]. Berry Gordy's whole family had the front row. Well, nobody told George not to trip, 'cause we had a green light to do whatever we wanted to do in the Twenty Grand. He took off his clothes and jumped right down on Berry Gordy's table, and Berry Gordy's wife was there, and his mother and father. And told Berry to 
Embracing perversity for all that it is worth, Clinton's improvisational and sometimes wacked-out style performs his body's status as free - as the property only of a boundless black imagination. As Clinton tells J ohn Corbett:

The Temptations and the Pips had their type of thing wrapped up -- the choreography, the outfits.. Instead of wearing suits we'd just gotten pressed, we'd wear the bags that they came back from the cleaners in. We'd just bust holes where the legs and arms would go. If we were on the road and we didn't have the costume, I'd take a sheet from the hotel and just dump whatever I had around it (Corbett 13).

Certainly, in Clinton's description of their improvisational tactics, we see a rejection of the codes of respectability pushed by Motown and others. Though Motown's Berry Gordy and George Clinton at one time collaborated in Clinton's early days, the relationship between the two was during the days of P-Funk heated competition, mutual influence and/ or stealing riffs, and playful animosity. One might see Clinton's commentary on Motown as part of the band's ongoing critique, or at least complication, of the image of the black male entertainer, along with the minstrel, the pimp, and the hypermasculine gangster, interrupting and reconfiguring the selling of black masculinity for others' pleasure. And we might think of the crazy stagecraft- the wildly oversized flashlights, the ingenuous dooby-smoking skull, and of course, the Mothership itself-as other expressions of creative freedom. Indeed, Clinton designed and paid for these sets himself, taking the profits that other performers might

kiss his ass. You didn't sign me before, now kiss my ass!

George: No, hell naw. . Naw, I an't do no kiss my ass. Everbody tells those lies.. I was naked, probably. And I probably poured some wine over my head, then it dripped all down my dick, and as I run across all the tables in there - I don't know if Berry was there, but I know the family was thereI would run up and down the table, up the bar, and wine would drip down so everybody say it looked like I peed in everybody's drink. But I was too out of it to even know if I did it or not.

(Marsh 62-63). 
have used for a Cadillac or a house for their mother, and used them for costumes, space ships, and birthing pods.

\section{Queering Black Cultural Traffic: P-Funk and the Entertainment Industry}

Though sometimes gentle, sometimes pointed in his critiques of Motown, Disco, Blue-eyed soul and other commercialized forms of black music, George Clinton makes black cultural traffic one of his central points of political concern:

Hey I was diggin' on y'alls funk for awhile. Sounds likeit got a three on it though, to me. Then I was down south and I heard some funk with some main ingredients

Like Doobie Brothers, Blue Magic, David Bowie. It was cool,

But can you imagine Doobiein' your funk? (PFunk "Wants to get Funked Up")

Clinton does not attempt to place P-Funk above the forces of commercialization and other aspects of black cultural traffic and trade. Instead, the band allows for the messiness, including cross-influence across lines of race, genre, power, as well as corniness and cool. In an answer to the high number of unacknowledged samples of his music, Clinton has both gone to the courts, and produced an album of frequently sampled songs called "Sample Some a Disc, Sample Some a Dat," which includes an application form for use of copyright materials. This acknowledgement of the messiness of musical influence can also be seen performatively in the songs themselves. The band sometimes dared to Doobie' its funk, taking on consummately “White” pop standards and lending them a hard funk edge. Band manager Bob Dedeckere describes one late 1970's P-Funk set as that which moves from "Dixie" to "Do You think I'm Sexy" to their own "Maggot Brain." Indeed, the band's relationship to white rock in some ways acknowledges cross influence, as well as the borrowing and reborrowing of black sound. ${ }^{29}$ I hear in

\footnotetext{
${ }^{29}$ At the same time, in songs like "U.S. Customs Dope Dogs" and others, Clinton offers an explicit and heated critique of institutional powers of policing and commerce, suing and countersuing Warner Brothers to have control over the masters of his music, and at several points forming his own label to have more economic and creative control
} 
Clinton's rerecording of Cream's "Sunshine of Your Love," featuring Brian McKnight's one man multiple guitar workover, as a form of (loving) revenge. Each return to the bridge keeps topping itself, reaching higher and higher, betraying the calm steady beat of the drums. Clinton says of the song, "We took the motherfucker and roughed it up." 30 At the same time, Clinton has willingly collaborated with a new generation of white performers influenced by P-Funk's song and style. Since going solo, Clinton has performed live with Phish, The Red Hot Chili Peppers, and has produced and recorded with a variety of other artists.

P-Funk is not afraid to situate its music in a history that is both violent and comical, and that can't be completely transcended, even by a mothership. Bassist William "Billy Bass" Nelson speaks about the multiple influences of acid and psychedelic rock on his sound:

Sgt. Pepper's Lonely Hearts Club Band, that motherfucking record turned me the fuck out, for that direction - more like a pop-rock type of thing. Blue Cheer and J imi Hendrix turned me out for acid rock. And Cream turned me out for the bluesy kind of rock. And I listened to those albums

over his music. Clinton comments on his own, sometimes indirect strategies of critique:

I keep it tongue in check, 'cause I ain't into preachin' and anything people got to get they got to be able to get it and able to think about it, they can't get it, jump up and do nothin' about it other than think, 'cause the minute you start to go crazy, they prepared to tear this country up. They don't care nothing bout this country. The people that's in charge is a very small number of bankers, federal reserve, secret organizations and shit like that. They don't care which country stand and which country go. They could care the fuck less about that. Matter of fact there's more money, cause they usually have a bank financin' both sides of any war. That's all it is. So it's a waste of hip-hop or rap or kids' energy to be pissed at a cop. Cop is a broke motherfucker! My thang is, I ain't gonna be mad at no mother broke as me. ... There's always somebody pullin' strings in black and white situation (Corbett 283-284).

${ }^{30}$ Quoted in David Gonzalez, "Is there Life After Jimi," Newsweek, April 30 $0^{\text {th }}$, 1990, page 68. 
diligently, every day, until I knew all the songs, note for note. After I heard that stuff, I knew that I couldn't just play rhythm and blues constantly. I had to be able to branch out and play it all. (Billy Bass in Marsh 32).

I think that the repeated use of the phrase "turned out" in Nelson's description is significant and suggestive. The term refers to an extreme and perhaps ecstatic reversal of previous thinking-- having one's proverbial mind blown. It also has more visceral, even sexual connotations-literally being turned inside out. In some sexual slang, the term refers to being "turned" in terms of sexual orientation ${ }^{31}$ or of being raped, or prostituted. Bass's choice of words not only speaks of the ways that his view of black music was turned inside out - the ways that white rock forced him to think about the relationship between white and black sound, not as opposites but as being of the same family. It also recalls a deeper cultural memory -- the "primal moment" of sorts of the "rape" of black sound and laborthe history of abjection of black performers in the United States as unacknowledged sources of rock and pop. P-Funk resists complete erasure of this history, and interestingly conceptualizes music listening and musical performance as a mixture of pleasure and pain, abjection and remastery. ${ }^{32}$

${ }^{31}$ Anthropologist Aimee Cox, in her study of gender and sexuality of black women and girls, notes the use of the phrase being "turned out" to mean opening oneself up to the possibilities of a fluid sexuality in her essay, "Thugs, Black Divas and Gendered Aspirations” in Souls 11 (2) 113-114, 209, page 132. She writes that "Getting turned out does not necessarily mean that a young woman has taken on a new sexual identity but that she has . . .become open to the possibilities” (Cox 132).

${ }^{32}$ Bass describes in more detail this experience of being altered by listening to and playing with white rockers in Marsh:

We were playing at Sacred Heart College in Connecticut, and something happened that our equipment got delayed on the road, it never made it to the gig. J us so happened that Vanilla Fudge was on the gig with us-opening for us, okay? Vanilla Fudge, the opening act. And they let us use their equipment. The guitar player had a doublestack of Marshalls, and the bass player was using a 
Ultimately, then, P-Funk's quest for imaginative freedom is informed by the history of the black body as it works and reworks history.

In his forward to the book, Speak My Name: Black Men on Masculinity and the American Dream, playwright August Wilson writes that "Reduced to its most fundamental truth, black men are a commodity of flesh and muscle which has lost its value in the marketplace. We are left over from history" (Wilson, Speak My Name xi). PFunk, and its interest in grooving, vamping, being turned out and reanimated through sound, presents an extraordinary realignment of the black male body in labor. As Clinton describes it, "We had a groove that was religious. We could vamp forever" (Marsh 41-42). Instead of the image of the black male body used up through the labors of nation building voiced by August Wilson, P-Funk offers up a new relationship to work, where sweat leads to pleasure and exploration; where the black male body might be viewed under new terms of value.

Yet P-Funk's style is not meant to be a complete escape from reality, and the more familiar struggles of home. We are meant, I think, to consider the work that goes into the production of P-Funk's musical performances, in the same way that we are meant to see them (and ourselves) sweat as we dance. For Michael Ladd, P-Funks dirty costumes and other less than perfect aspects of stage craft were part of its political vision, the ways that the fantasy was not meant to be one of escape, but return:

They got their image from everywhere but primarily from the broom closet or the trash. They were beyond their world; they were out of this world. My friend Michel, horn player and flutist, remembers seeing them at the Apollo Theater in

triple-stack of S.V.T.s, Amps, and the drummer had some set of great big oversized-I think those were the first fibes that we'd ever seen, fiberglass drums. That 's how we found out we'd been using the wrong equipment all along for the sound we had and what we were trying to approach. We needed that Marshall, and I needed them S.V.T's . And within a few weeks, we had 'em. That's when we really changed from rhythm and blues, Motown wannabees into what we evolved into the real Funkadelic. Those amps, and that big oversized set of drums Tiki had (Billy Bass in Marsh 33). 
1977; "Shider was wearing a diaper like he always did, and he had these elevator boots on but they weren't fly, they were worn, like really worn. Then out comes George in a baby-blue sheet with Roadrunner and Wily Coyote on it and the sheet is not clean. He's got a bike chain around his waist for a belt. I mean, it looked like he grabbed the first thing he saw when he was walking out the door and was like, 'Fuck it, I'll wear this.'”' (Ladd 74-75).

For Ladd, P-Funk's creative style marks its travel produced from a history of struggle. This creative refashioning provides an important model for black men in the PostSoul Era to re-experience their bodies in history. P-Funk both acknowledges the costs of history, the funk of a history of struggle, as well as a way out, a possibility for something new by way of humor, vulnerability and emotional openness.

Take for example, some recent eruptions of P-Funk in writing about black men's coming of age. In all three of these examples, the sounds of P-Funk provide an entryway to new ways of being for Post-Soul men, where gender, sexuality and class prove constrictive. While the paths that P-Funk offer are inchoate in their advice on how to proceed, they serve to encourage each speaker to create something new, to rebel, and especially to dig deeper into modes of desire and embodiment that may have been otherwise ignored by their families and communities.

Poet Kenneth Carroll, who grew up in the Montana Terrace Projects in Washington D.C., remembers the profound impact that the music and cover art of Parliament Funkadelic had on him and his male friends, as a space where he and his friends found a rare pleasure in critical interrogation, imaginative freedom and selffashioning:

Guys who literally could not read would be interpreting the pictures, the art work, and they would come over my crib. We'd be in my living room, going over what it meant. Kids played hookey from school to line up in front of a downtown record store on the day Parliament Mothership Connection LP came out, he says. A crew of older kids carried P-Funk albums from party to party, and invented dances, and became a self-styled "funk mob." Part of the thing was that, for a lot of us in the inner city, they literally kind of opened the world up. In the framework of their music, there's a possibility of being beyond. That 
you can literally exist as a Child of the Universe somewhere, where color and class and none of that really matters. That people could be something else besides, you know, po' niggas (Mills C1).

Carroll and his friends' critical "funk mob" might be the visual and aural model of bell hooks's "oppositional gaze" - the practice of critical looking (and listening) as a form of pleasure and power, the key to a decolonized mind. ${ }^{33}$ She writes, "By courageously looking, we defiantly declared, "Not only will I stare. I want my look to change reality" (hooks 116). Along with the pleasures of disorientation, PFunk's music and visuals offer space to imagine new possibilities for oneself and each other.

For writer/ critic Michael C. Ladd, Funkadelic and especially the early music of Maggot Brain and Cosmic Slop become a space of escape from the normative pressures of black middle-class men coming of age in Boston: dressing "seditty," combing one's fro, or keeping it cut short nice and tight:

My mother, like any sensible black woman of her age, was big on appearance. Getting me to dress well was a constant struggle. Attempting to drag a comb through my afro was near impossible. I'd pull a William and Ellen Craft and just start running. I would run until I had exhausted by mother and aunt's energy and the pick would slip from their hands. But I felt like the world was against me on this one. Everyone was snap tight UpSouth. Needless to say, when I saw the Funkadelic covers I felt I had finally found some company - big, bushy muthafuckas. They were the masters of the margin, right in the middle." (Ladd 72)

While Ladd doesn't talk specifically about the link between Funkadelic and sex, the music becomes his alternate

\footnotetext{
${ }^{33}$ See "The Oppositional Gaze” in bell hooks, Black Looks (Boston: South End Press, 1992) pages 115-131. hooks might well add oppositional listening to her conceptualization of critical engagement, here. She models oppositional listening in her critical work on hip-hop, including her 1994 essay, "Sexism and Misogyny: Who takes the Rap: Misogyny, Gangsta Rap and The Piano” in Z Magazine, February 1994.

http://race.eserver.org/misogyny.html.
} 
soundtrack for the politics of gender and (sexual) coming of age around him, and is a part of his own awareness of his body, and his fashioning of it, as a site of contested ownership:

Grit, and nappy and ashy kneecapped grit is what I needed. I didn't wash already, that's whom I was, a complicated black kid bouncing from a faux ghetto to suburbia and back, in the same town. . . .I found Cosmic Slop at my cousins'. It did not save my life. It just gave me the map so I knew how. (Ladd 72)

Finally, we might consider P-Funk Bassist Bootsy Collins's narrative of discovery and becoming a part of George Clinton's Band, in this interview with Thomas Sayers Ellis, as an example of how the blaxploration that P-Funk offers its audiences also works internally, for its creators. Bootsy offers another example of the ways that the band opens up the constraints of normative black masculine performance. For Bootsy, his collaboration with George Clinton becomes a way to move beyond the musical and sartorial aesthetic of respectability and high style embraced by J ames Brown's band, for something more experimental. Bootsy describes showing up to his first J ames Brown session in 1969, with "tied died jeans, my Afro was leaning to the right. And we were wearing them little round eyeglasses from back in the day. J ust cool." - but out of step with the aesthetic of smooth soulfulness of J ames Brown and his review. ${ }^{34}$ An invitation to hold down the bass in The Godfather of Soul's band was an amazing professional opportunity. Bootsy describes his apprenticeship with Brown as a time when helearned discipline and, in some ways, a route of respect as a fatherless son. Bootsy also describes his yearning to play outside of the bounds of Brown's direction:

'Son, listen to me now. I'm the Godfather of Soul.' He always had to lecture me and it was oool

\footnotetext{
${ }^{34}$ Alice Echols discusses James Brown's embrace of sophistication as a sartorial style in her essay "The Land of Somewhere Else: Refiguring James Brown in Seventies Disco" in Criticism, Winter 2008, Vol. 50 , No. 1, pages 19-41, especially pages 28-30. Despite his raw shouts and stripped down beats, Brown saw smooth processed hair, and expensive, well-cut suits as part of his performative stance of pride, and political and artistic cosmopolitanism and control.
} 
because, like I said, I didn't have a daddy back home, so I guess he felt like he had to fill those shoes. And he was like my dad. 'Son, you got to stop doing all them things and just give me the One.' So when I started doing that, he started to like it and I could tell. So I figured, if I could give him this One and play all them other things. . . I think he'll like me (Ellis 92).

When there is an introduction of George Clinton's clearly more countercultural style to Bootsy, he finds a way out of the disciplining framework of family and patriarch. He goes to visit Clinton in his apartment and finds a new mode of blackness -- a soul mate for the self that he had to sacrifice in order to play in Brown's band:

I remember walking in the house. I'm kinda semitrippin' too. Walk in, and George didn't have no furniture, got no furniture in none of them. And he sittin' in the last room, in the corner, got his legs in like, a Buddha thing, you know, with his head down. He got a star on one side and a moon on the other shaved in his head and the rest was bald. He got a sheet on, his feet you know, he got these big "Boy, I say Boy" feet. You know who I'm talking about. Foghorn Leghorn! . . . And I'm like Dang, this is going to be fun (Ellis 95).

For Bootsy Collins, Ladd and Carroll, P-Funk's music provides a means of seeing around corners to a future that others can't see, and to provide new answers to those basic questions of desire and funk and freedom that plague them in the present. P-Funk shares its lessons in how to occupy the spaces of city streets, school yards, and concert stages in the full-on beauty of a new black masculine weirdness: ashy knee-capped, 'fro leaning to the side, playing to the One to the pulse of your own magnificent body. For its growing collective of Funkateers, P-Funk awakens otherwise unheard frequencies. Please do not adjust your set.

\section{References}

Bolden, Tony. "Theorizing the Funk: An Introduction" in The Funk Era and Beyond, edited by Tony Bolden. New York: Palgrave MacMillan, 2008, pages 13-29.

Brown, Scot. "A Land of Funk: Dayton Ohio" in The Funk Era and Beyond, edited by Tony Bolden. New York: Palgrave MacMillan, 2008, pages 73-88 . 
Byrd, Donald and Beverly Guy-Sheftall. Traps: African American Men on Gender and Sexuality. Indiana University Press, 2001.

Cohen, Cathy. "Punks, Bulldaggers, and Welfare Queens: The Radical Potential of Queer Politics?" in Queer Black Studies: A Critical Anthology, edited by Mae Henderson and E. Patrick J ohnson. Durham, NC: Duke University Press, 2005, pages 21-51.

Corbett, J ohn. Extended Play: Sounding Off from J ohn Cage to Dr. Funkenstein. Durham: Duke University Press, 1994.

Cox, Aimee. "Thugs, Black Divas and Gendered Aspirations". Souls 11 (2) pages 113-141.

Cox, Tom. "Funkenstein Lives: George Clinton is 60, but he's as barmy as ever". The Guardian (London). July 21, 2000, page 14.

Cruse, Harold. The Crisis of the Negro Intellectual. New York: Quill Press, 1984.

Danielsen, Ann. Presence and Pleasure: The Funk Grooves of J ames Brown and Parliament (Middletown, CT: Wesleyan University Press, 2006.

DeRogotis, Jim. Turn on Your Min: Four Decades of Great Psychedelic Rock. New York: Hal Leonard, 2003.

Echols, Alice. "The Land of Somewhere Else: Refiguring J ames Brown in Seventies Disco" in Criticism, Winter 2008, Vol. 50 No. 1, pages 19-41.

Ellis, Thomas Sayers. "From the Crib to the Coliseum: An Interview with Bootsy Collins," in The Funk Era and Beyond, edited by Tony Bolden. New York: Palgrave MacMillan, 2008, pages 89-106.

Eshun, Kodwo. More Brilliant than the Sun: Adventures in Sonic Fiction. London: Quartet Books, 1998.

Franzen, Benjamin. Copyright Criminals (film, 2008).

Gilroy, Paul. The Black Atlantic: Modernity and DoubleConsciousness. Cambridge: Harvard University Press, 1993.

hooks, bell. Black Looks. Boston: South End Press, 1992.

---. "Sexism and Misogyny: Who takes the Rap: Misogyny, Gangsta Rap and The Piano" in Z Magazine, February 1994. http:// race.eserver.org/ misogyny.html.

Gonzalez, David. “Is there Life After Jimi,” Newsweek, 
April 30th, 1990, page 68.

Green, Tony. “Tracing Funk's Sources” St. Petersburg Times (FL), November 27th, 1994, page 1F.

Harper, Philip Brian. Are We Not Men? New York: Oxford University Press, 1996).

---. "The Evidence of Felt Intuition: Minority Experience, Everyday Life, and Critical Speculative Knowledge" in Queer Black Studies, edited by Mae Henderson and E. Patrick J ohnson. Duke University Press, 2005, pages 106-123.

Irigaray, Luce. This Sex Which is Not One. Ithaca: Cornell University Press, 1985.

J ohnson, E. Patrick. "Strange Fruit: A Performance about Identity Politics". TDR: The Drama Review, Volume 47, Number 2 (T 178), Summer 2003, pages 88-116.

J ones, Ann Rosalind. “Writing the Body: Toward an Understanding of l'Ecriture Feminine" in Feminisms: An Anthology of Literary Theory and Criticism, edited by Robin R. Warhol and Diana Price Herndl. New Brunswick, NJ : Rutgers University Press, 1997, pages 370-381.

Kelley, Robin D.G. "Confessions of a Nice Negro, or Why I Shaved my Head." in Speak My Name: Black Men on Masculinity and the American Dream, edited by Don Belton. Boston, MA: Beacon Press, 1995, pages 12-23.

Kempton, Arthur. Boogaloo: the Quintessence of American Popular Music. Ann Arbor, MI: University of Michigan Press, 2005.

Keyes, Cheryl. "Funkin' with Bach: the Impact of Professor Longhair on Rock ' $n$ ' Roll' in The Funk Era and Beyond, edited by Tony Bolden. New York: Palgrave MacMillan, 2008, pages 213-226.

Ladd, Michael. "Staring at the Cosmic Slop: The Mothershp Connection between Triple and Quadruple Consciousness," in Rip It Up: Black Experience in Rock ' $n$ ' Roll, edited by Kandia Crazy Horse. New York: Palgrave MacMillan, 2004, pages 71-84.

Lipsitz, George. Footsteps on the Dark: The Hidden Histories of Popular Music. Minneapolis: Minnesota University Press, 2007.

Marsh, Dave. For the Record: George Clinton and P-Funk: An Oral History, edited by David Marsh. New York: Avon Books, 1998. 
Mutua, Athena. Progressive Black Masculinities.New York: Routledge, 2006,

Neal, Mark Anthony. New Black Man. NewYork: Routledge, 2006.

---. What the Music Said: Black Popular Music and Black Public Culture (New York: Routledge, 1999.

Palmer, Robert. "The Pop Life: Clinton's Satire has a Bite," The New York Times, May 7, 1986, section c, page 26.

Phelps, Carmen. "Living the Funk: Lifestyle, Lyricism and Lessons in Modern and Contemporary Art of Black Women”The Funk Era and Beyond, edited by Tony Bolden (New York: Palgrave MacMillan, 2008) 213226.

Reid-Pharr, Robert. Gay Black Man: Essays. New York: New York University Press, 2001.

Smith, Barbara. Home Girls: A Black Feminist Anthology. New Brunswick, NY: Rutgers University Press, 2000.

Stockton, Kay Bond. Beautiful Bottom, Beautiful Shame: Where "Black" meets "Queer." Durham, NC: Duke University Press, 2006.

Vincent, Rickey. Funk: The Music, Peopleand the Rhythm of the One. St. Martin's Press, 1996.

Walcott, Rinaldo. 'Reconstructing Manhood, or, The Drag of Black Masculinity" in Small Ax 13 (1), 75.

Williams, Patricia. "Meditations on Masculinities" Callaloo Vol. 19, number 4, Fall, 1996, pages 814-822.

Wright, Amy Nathan. "A Philosophy of Funk: The Politics and Pleasure of a Parliamentfunkadelicment Thang!" in The Funk Era and Beyond: New Perspectives on Black Popular Culture, edited by Tony Bolden (New York: Palgrave MacMillan, 2008) pages 33-50.

Zibart, Eve. "A Summer Day of 'ChocolateJ am': The 'Chocolate Jam,' an All-Day Celebration of Music". The Washington Post, J uly 3, 1978, page B1. 